\title{
Some compounds isolated from leaves of Lumnitzera racemosa growing in Vietnam
}

- Nguyen Hoai Phuong

- Nguyen Thi Le Thuy

- Nguyen Trung Duc

- Nguyen Thi Thanh Mai

- Nguyen Kim Phi Phung

University of Science, VNU-HCM

(Received on $16^{\text {th }}$ November 2016, accepted on $30^{\text {th }}$ October 2017)

\section{ABSTRACT}

From L. racemosa leaves eight compounds were isolated: myricetin (1), quercetin (2), myricetin 3-O- $\alpha$-L-rhamnopyranoside (3), myricetin 3-O-(2"-O-galloyl- $\alpha-L-$ rhamnopyranoside) (4), myricetin 3-O-(3"-Ogalloyl- $\alpha$-L-rhamnopyranoside) (5), 3-Omethylellagic acid (6), (3S,5R,6S,7E)-3,5,6trihydroxy-7-megastigmen-9-one (7) and gallic acid (8). Their chemical structures were Key words: Lumnitzera racemosa Willd., Lumnitzera, Flavonoid, Megastigmane sesquiterpene

\section{INTRODUCTION}

Lumnitzera racemosa, an Indo-West Pacific mangrove plant, wildly grows in many mangrove forests in Vietnam. Some extracts from Lumnitzera racemosa leaves were reported to possess bioactivities, e.g. antimicrobial, hepatoprotective and antioxidant. This species was traditionally used to treat asthma, diabetes and snake bite. Some reports on the chemical constituents of Lumnitzera racemosa have been reported and there had one study on the antioxidant and cytotoxic activities of this plant growing in Vietnam [3]

\section{MATERIALS AND METHOD}

\section{General}

The NMR spectra were measured on a Bruker Avance spectrometer, at $500 \mathrm{MHz}$ for ${ }^{1} \mathrm{H}$ and $125 \mathrm{MHz}$ for ${ }^{13} \mathrm{C}$; the HR-ESI-MS were recorded on a HR-ESI-MS MicrOTOF-Q mass unambiguously elucidated by analysis of $1 D$ and 2D NMR and high resolution ESI mass spectroscopic data, as well as by comparison with those reported in the literature. The $\alpha$ glucosidase inhibition was evaluated on isolated compounds. Among them, 1, 4, 5, 6 and 8 exhibited good activities with the $I C_{50}$ values in the range of $1.3-19.3 \mu M$.

spectrometer in the University of Science, National University - HCM City.

\section{Plant material}

Leaves of L. racemosa Willd. (Combretaceae) were collected in $\mathrm{Ha}$ Tien district, Kien Giang province, Viet Nam in August of 2014. The scientific name of plant was identified by Faculty of Biology Biotechnology, University of Science, VNUHCM.

\section{Extraction and isolation}

Fresh leaves $(30 \mathrm{~kg}$ ) were washed, dried, ground into powder $(10 \mathrm{~kg})$ and extracted by maceration with methanol at room temperature then the extracted solution was evaporated at reduced pressure to give a methanol residue $(1,500 \mathrm{~g})$. Approximately $1,200 \mathrm{~g}$ of this methanol residue was applied to the solid phase extraction eluted consecutively with petroleum ether - ethyl acetate (5:5), ethyl acetate, ethyl

Trang 20 
acetate - methanol $(9: 1)$ and ethyl acetate methanol $(8: 2)$. The extracted solutions were evaporated at reduced pressure to afford four types of extracts: A extract (50 g), B extract (50 g), C extract (48 g) and D extract $(80 \mathrm{~g})$, respectively. The $\mathrm{C}$ extract (48 $\mathrm{g}$ ) was silica gel chromatographed (column $120 \times 6 \mathrm{~cm}$ ), eluted with petroleum ether-ethyl acetate (stepwise 1:1 and $0: 1)$ and then ethyl acetate-methanol (stepwise, 9:1, 4:1, 1:1, 0:1) to give eight fractions $(\mathrm{C} 1-\mathrm{C} 8)$. Fractions $\mathrm{C} 3$ and $\mathrm{C} 4$ were rechromatographed over Sephadex LH-20 and then on silica gel using $\mathrm{CHCl}_{3}-\mathrm{MeOH}$ (1: 0 to 9 : 1) to afford (1) $(30 \mathrm{mg}),(\mathbf{2})(15 \mathrm{mg}),(3)$ (100 $\mathrm{mg})$, (4) (30 mg) and (5) (15 mg). Fraction C8 $(22 \mathrm{~g})$ was subjected to a reversed phase chromatography (column $60 \times 4 \mathrm{~cm}$ ) eluted with with water - methanol (stepwise, 1:0, 9:1, 4:1, $1: 1,0: 1)$ to obtain (6) (10 mg) and (7) (5 mg). $100 \mathrm{mg}$ of the B extract was applied to Sephadex LH20 chromatography to obtain (8) (30 mg).

Myricetin (1). Yellow powder. HR-ESI-MS: $\mathrm{m} / \mathrm{z} 317.0315$ corresponded to the molecular formula of $\mathrm{C}_{15} \mathrm{H}_{10} \mathrm{O}_{8} \quad\left(\mathrm{C}_{15} \mathrm{H}_{10} \mathrm{O}_{8}-\mathrm{H}, 317.0336\right.$, error of 2.1 millimass). ${ }^{1} \mathrm{H}-\mathrm{NMR}$ (DMSO- $\left.d_{6}\right), \delta_{\mathrm{H}}$ $6.18(1 \mathrm{H}, d, 2.0 \mathrm{~Hz}), 6.36(1 \mathrm{H}, d, 2.0 \mathrm{~Hz}), 7.24$ $(2 \mathrm{H}, s) .{ }^{13} \mathrm{C}-\mathrm{NMR}$ (DMSO- $\left.d_{6}\right), \delta_{\mathrm{C}} 175.8(\mathrm{C}-4)$, 164.0 (C-7), 160.7 (C-5), 146.8 (C-2), 145.7 (C3', 5'), $135.9\left(\mathrm{C}-3,4^{\prime}\right), 107.2\left(\mathrm{C}-2^{\prime}, 6^{\prime}\right), 98.2(\mathrm{C}-$ 6) and $93.2(\mathrm{C}-8)$.

Quercetin (2). Yellow powder. ${ }^{1} \mathrm{H}$ NMR, $\left(\mathrm{CDCl}_{3}\right), \delta_{\mathrm{H}} 6.18(1 \mathrm{H}, d, 2.0 \mathrm{~Hz}), 6.40(1 \mathrm{H}, d, 2.0$ $\mathrm{Hz}), 7.67(1 \mathrm{H}, d, 2.5 \mathrm{~Hz}), 6.88(1 \mathrm{H}, d, 8.5 \mathrm{~Hz})$, $7.53(1 \mathrm{H}, d d, 8.5,2.0 \mathrm{~Hz}) .{ }^{13} \mathrm{C}-\mathrm{NMR}$ (DMSO- $\left.d_{6}\right)$, $\delta_{\mathrm{C}} 175.8$ (C-4), 163.9 (C-7), 160.7 (C-5), 156.1 (C-9), $147.7\left(\mathrm{C}-4^{\prime}\right), 146.8(\mathrm{C}-2), 145.0\left(\mathrm{C}-3^{\prime}\right)$, 135.7 (C-3), $121.9\left(\mathrm{C}-1^{\prime}\right), 120.0\left(\mathrm{C}-6^{\prime}\right), 115.6$ (C5'), $115.0\left(\mathrm{C}-2^{\prime}\right), 103.0(\mathrm{C}-10), 98.2(\mathrm{C}-6)$ and 93.3 (C-8).

Myricetin 3-O- $\alpha$-L-rhamnopyranoside (3). Yellow powder. NMR data, see Table 1.
Myricetin

3-O-(2"- $O$-galloyl- $\alpha-\mathrm{L}-$ rhamnopyranoside) (4). Yellow powder. HR-ESIMS: $m / z, 615.0971$ corresponded to the molecular formula of $\mathrm{C}_{28} \mathrm{H}_{24} \mathrm{O}_{16}\left(\mathrm{C}_{28} \mathrm{H}_{24} \mathrm{O}_{16}-\mathrm{H}, 615.0986\right.$, error of 1.5 millimass). NMR data, see Table 1.

Myricetin 3-O-(3"'-O-galloyl- $\alpha$-Lrhamnopyranoside) (5). Yellow powder. NMR data, see Table 1.

3-O-Methylellagic acid (6). Pale yellow powder. HR-ESI-MS: $m / z \quad 315.0120$ is corresponded to molecular formula of $\mathrm{C}_{15} \mathrm{H}_{8} \mathrm{O}_{8}$ $\left(\mathrm{C}_{15} \mathrm{H}_{8} \mathrm{O}_{8}-\mathrm{H}, 315.0141\right.$, error of 2.1 millimass $)$. ${ }^{1} \mathrm{H}-\mathrm{NMR}$ (DMSO- $\left.d_{6}\right), \delta_{H} 7.51(1 \mathrm{H}, s), 7.42(1 \mathrm{H}$, $s), 4.03(3 \mathrm{H}, s) .{ }^{13} \mathrm{C}-\mathrm{NMR}$ (DMSO- $\left.d_{6}\right), \delta_{\mathrm{C}} 159.1$ (C-7), $158.9\left(\mathrm{C}-7^{\prime}\right) 152.0$ (C-4), 148.7 (C-4'), 141.6 (C-2), $141.0\left(\mathrm{C}-3^{\prime}\right), 140.2$ (C-3), 136.0 (C2'), 112.6 (C-6), 112.4 (C-1), 112.1 (C-1'), 111.3 (C-5), $109.8\left(\mathrm{C}-5^{\prime}\right)$, and $60.9\left(\mathrm{OCH}_{3}\right)$

$(3 S, 5 R, 6 S, 7 E)-3,5,6-$ Trihydroxy-7megastigmen-9-one (7). $[\propto]_{D}^{25}-199.9$ (c 0.08 , $\mathrm{CHCl}_{3}$ ). ${ }^{1} \mathrm{H}-\mathrm{NMR}$ (DMSO- $\left.d_{6}\right), \delta_{\mathrm{H}} 0.87(3 \mathrm{H}, s)$, $1.11(3 \mathrm{H}, \mathrm{s}), 1.13(3 \mathrm{H}, s), 1.25(1 \mathrm{H}, d d, 13.0$, $10.5 \mathrm{~Hz}), 1.62(1 \mathrm{H}, d d d, 13.0,3.5,1.0 \mathrm{~Hz}), 1.73$ $(1 \mathrm{H}, d d, 14.5,9.0 \mathrm{~Hz}), 2.25(3 \mathrm{H}, s), 2.36(1 \mathrm{H}$, $d d d, 14.5,5.0,1.0 \mathrm{~Hz}), 4.17(1 \mathrm{H}, m), 6.03(1 \mathrm{H}, d$, $16.0 \mathrm{~Hz}), 7.07(1 \mathrm{H}, d, 16.0 \mathrm{~Hz}) .{ }^{13} \mathrm{C}-\mathrm{NMR}$ (DMSO- $\left.d_{6}\right), \delta_{\mathrm{C}} 197.4$ (C-9), 143.0 (C-7), 132.4 (C-8), 68.9 (C-6), 68.7 (C-5), 68.3 (C-3), 43.2 (C-2), 37.7 (C-4), 34.5 (C-1), 28.7 (C-13), 27.4 (C-10), 25.0 (C-11), and 19.7 (C-12)

Gallic acid (8). White powder. ${ }^{1} \mathrm{H}-\mathrm{NMR}$ $\left(\mathrm{DMSO}-d_{6}\right), \delta_{\mathrm{H}} 6.91(2 \mathrm{H}, s) .{ }^{13} \mathrm{C}-\mathrm{NMR}$ (DMSO$\left.d_{6}\right), \delta_{\mathrm{C}} 167.5(\mathrm{COOH}), 145.4(\mathrm{C}-3, \mathrm{C}-5), 138.0$ (C-4), 120.5 (C-1), and 108.7 (C-2, C-6).

\section{Bioassay}

The inhibitory activity of $\alpha$-glucosidase was determined according to the modified method of Kim et al. [2]. $3 \mathrm{mM}$-nitrophenyl- $\alpha$-Dglucopyranoside $(25 \mu \mathrm{L})$ and $0.2 \mathrm{U} / \mathrm{mL} \alpha$ glucosidase $(25 \mu \mathrm{L})$ in $0.01 \mathrm{M}$ phosphate buffer $(\mathrm{pH}=7.0)$ were added to the sample solution 
$(625 \mu \mathrm{L})$ to start the reaction. Each reaction was performed at $37{ }^{\circ} \mathrm{C}$ for $30 \mathrm{~min}$ and stopped by adding $0.1 \mathrm{M} \mathrm{Na} \mathrm{Na}_{3}(375 \mu \mathrm{L})$. Enzymatic activity was quantified by measuring the absorbance at $401 \mathrm{~nm}$. One unit of $\alpha$-glucosidase activity was defined as the amount of enzyme liberating $p$-nitrophenol $(1.0 \mu \mathrm{M})$ per min. The $\mathrm{IC}_{50}$ value was defined as the concentration of $\alpha$ glucosidase inhibitor that inhibited $50 \%$ of $\alpha$ glucosidase activity. Acarbose, a known $\alpha$ glucosidase inhibitor, was used as a positive control. The result was presented in Table 2.

\section{RESULTS AND DISCUSSION}

Isolation and purification of compounds from Lumnitzera racemosa leaves were performed using combinations of chromatographic fractionation of some ethyl acetate extracts to afford eight compounds (1-8) (Fig. 3). Their structures were elucidated as the following.

The HR-ESI-MS spectrum of (1) gave a quasimolecular ion peak at $\mathrm{m} / z$ 317.0315 [M-H] corresponding to the molecular formula of $\mathrm{C}_{15} \mathrm{H}_{10} \mathrm{O}_{8}$. The ${ }^{1} \mathrm{H}-\mathrm{NMR}$ spectrum of (1) in DMSO-d6 showed a down field signal at $\delta_{H}$ $12.49(1 \mathrm{H}, s)$ indicating the presence of a chelated hydroxyl at C-5 position. Two metacoupled doublet proton signals at $\delta_{H} 6.18(1 \mathrm{H}, d$, $2.0 \mathrm{~Hz})$ and $6.36(1 \mathrm{H}, d, 2.0 \mathrm{~Hz})$ were assigned to $\mathrm{H}-6$ and $\mathrm{H}-8$, respectively, of ring $\mathrm{A}$ of the 5,7dihydroxyflavonoid. Moreover, a singlet signal at $\delta_{H} 7.24(2 \mathrm{H}, s)$ was characteristic of a symmetric $\mathrm{B}$ ring. These spectral data revealed the presence of a myricetin skeleton. The good compatibility between these NMR data of (1) and those reported in the literature [6] confirmed its structure to be myricetin.

Table 1. NMR data of 3,4 and 5

\begin{tabular}{|c|c|c|c|c|c|c|}
\hline \multirow[t]{2}{*}{ Pos. } & \multicolumn{2}{|l|}{$3\left(\mathrm{DMSO}-d_{6}\right)$} & \multicolumn{2}{|l|}{$4\left(\mathrm{DMSO}-d_{6}\right)$} & \multicolumn{2}{|c|}{$5\left(\mathrm{DMSO}-d_{6}\right)$} \\
\hline & $\delta_{H}, \mathrm{~J}(\mathrm{~Hz})$ & $\delta_{C}$ & $\delta_{H}, \mathrm{~J}(\mathrm{~Hz})$ & $\delta_{C}$ & $\delta_{H}, \mathrm{~J}(\mathrm{~Hz})$ & $\delta c$ \\
\hline 2 & & 156.4 & & 157.5 & & 157.6 \\
\hline 3 & & 134.3 & & 133.5 & & 134.9 \\
\hline 4 & & 177.8 & & 177.5 & & 177.8 \\
\hline 5 & & 161.3 & & 161.3 & & 161.3 \\
\hline 6 & $6.18(1 \mathrm{H}, d, 2.0)$ & 98.6 & $6.20(1 \mathrm{H}, d, 1.5)$ & 98.3 & $6.21(1 \mathrm{H}, d, 2.0)$ & 98.7 \\
\hline 7 & & 164.2 & & 164.2 & & 165.7 \\
\hline 8 & $6.34(1 \mathrm{H}, d, 2.0)$ & 93.5 & $6.37(1 \mathrm{H}, d, 1.5)$ & 93.6 & $6.38(1 \mathrm{H}, d, 2.0)$ & 93.6 \\
\hline 9 & & 157.5 & & 156.4 & & 156.5 \\
\hline 10 & & 104.0 & & 104.0 & & 104.1 \\
\hline 1 ' & & 119.6 & & 119.4 & & 119.6 \\
\hline $2^{\prime}, 6^{\prime}$ & $6.87(2 \mathrm{H}, s)$ & 107.9 & $6.92(2 \mathrm{H}, s)$ & 108.0 & $6.89(2 \mathrm{H}, \mathrm{s})$ & 107.9 \\
\hline $3^{\prime}, 5^{\prime}$ & & 145.8 & & 145.8 & & 145.8 \\
\hline $4^{\prime}$ & & 136.4 & & 136.6 & & 136.8 \\
\hline $1^{\prime \prime}$ & $5.18(1 \mathrm{H}, d, 1.5)$ & 101.9 & $5.50(1 \mathrm{H}, d, 1.5)$ & 98.7 & $5.03(1 \mathrm{H}, b r s)$ & 102.7 \\
\hline $2^{\prime \prime}$ & $3.96(1 \mathrm{H}, d d, 1.5,3.5)$ & 70.0 & $5.48(1 \mathrm{H}, d d, 1.5,3.5)$ & 71.7 & $4.30(1 \mathrm{H}, b r s)$ & 67.8 \\
\hline $3^{\prime \prime}$ & $3.53(1 \mathrm{H}, d d, 3.5,9.5)$ & 70.4 & $3.78-3.82(1 \mathrm{H}, m)$ & 68.6 & $5.04(1 \mathrm{H}, m)$ & 73.9 \\
\hline $4^{\prime \prime}$ & $3.14(1 \mathrm{H}, t, 9.5)$ & 71.3 & $3.78-3.82(1 \mathrm{H}, m)$ & 71.8 & $3.42(1 \mathrm{H}, t, 6.5)$ & 68.6 \\
\hline $5^{\prime \prime}$ & $3.34-3.37(1 \mathrm{H}, m)$ & 70.5 & $3.78-3.82(1 \mathrm{H}, m)$ & 70.7 & $3.83(1 \mathrm{H}, m)$ & 70.9 \\
\hline $6^{\prime \prime}$ & $0.84(3 \mathrm{H}, d, 6.0)$ & 17.5 & $0.93(3 \mathrm{H}, d, 5.5)$ & 17.6 & $0.96(1 \mathrm{H}, d, 6.0)$ & 17.4 \\
\hline $\mathrm{C}=\mathrm{O}$ (galloyl) & - & - & & 165.0 & & 165.7 \\
\hline $1^{\prime \prime \prime}$ & - & - & & 119.3 & & 119.6 \\
\hline $2^{\prime \prime \prime}, 6^{\prime \prime \prime}$ & - & - & $6.95(2 \mathrm{H}, s)$ & 108.9 & $7.05(2 \mathrm{H}, s)$ & 109.0 \\
\hline $4 " \prime$ & - & - & & 138.5 & & 138.3 \\
\hline $\begin{array}{c}5^{\prime \prime \prime} \\
5-\mathrm{OH}\end{array}$ & $12.81 \overline{(1 \mathrm{H}, s)}$ & - & $12.54(1 \mathrm{H}, s)$ & 145.5 & $12.66(1 \mathrm{H}, s)$ & 145.4 \\
\hline
\end{tabular}

Trang 22 
<smiles>[R2]c1cc(-c2oc3cc(O)cc(O)c3c(=O)c2OC)cc([R1])c1O</smiles>

\begin{tabular}{lllll}
\multicolumn{1}{c}{ Compound } & & $\mathrm{R}_{1}$ & $\mathrm{R}_{2}$ & $\mathrm{R}_{3}$ \\
\hline Myricetin & $(1)$ & OH & OH & $\mathrm{H}$ \\
Quercetin & $(2)$ & OH & H & H \\
Myricitrin & $(3)$ & OH & OH & rhamnosyl \\
Myricitrin 2'"-O-gallate (4) & OH & OH & $(2 "-O$-galloyl)rhamnosyl \\
Myricitrin 3"'-O-gallate (5) & OH & OH & $(3 "-O$-galloyl)rhamnosyl
\end{tabular}

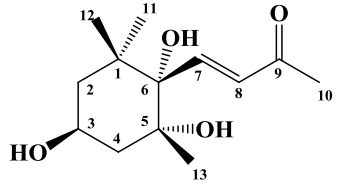

OH

Gallic acid (8)

Fig. 1. Isolated compounds from leaves of Lumnitzera racemosa Willd

Compounds (2) and (1) showed the similarities in proton signals at $\delta_{H} 12.5(1 \mathrm{H}, s)$, $6.40(1 \mathrm{H}, d, 2.0 \mathrm{~Hz}), 6.18(1 \mathrm{H}, d, 2.0 \mathrm{~Hz})$ indicating the ring $\mathrm{A}$ of 5,7-dihydroxyflavonoid. However, instead of a signal integrating for two protons, the presence of an $\mathrm{ABX}$ system at $\delta_{H}$ $7.67(1 \mathrm{H}, d, 2.5 \mathrm{~Hz}), 7.53(1 \mathrm{H}, d d, 8.5,2.0 \mathrm{~Hz})$ and $6.88(1 \mathrm{H}, d, 8.5 \mathrm{~Hz})$ corresponded to protons of the 1,3,4-trisubstituted phenyl group. The spectral data were compatible with those of quercetin [6].

Compound (3) and (1) showed similar spectral pattern but the former possessed a rhamnose moiety with proton signals at $\delta_{H} 5.18$ $\left(1 \mathrm{H}, d, 1.5 \mathrm{~Hz}, \mathrm{H}-1^{\prime \prime}\right)$ of an anomeric proton, 0.84 $\left(3 \mathrm{H}, d, 6.0 \mathrm{~Hz}, \mathrm{H}-6^{\prime \prime}\right)$, and signals from $\delta_{H} 3.0$ to 4.0 of an $\alpha$-L-rhamnose moiety. In addition, this anomeric proton showed the HMBC cross-peak with carbon $\mathrm{C}-3\left(\delta_{C} 134.3\right)$ proving that the sugar moiety linking to the aglycone at its C-3. The good compatibility between these NMR data of (3) and those reported in the literature [5] confirmed its structure to be myricetin $3-O-\alpha-\mathrm{L}-$ rhamnopyranoside.

The HR-ESI-MS spectrum of compound (4) gave a quasimolecular ion peak at $\mathrm{m} / \mathrm{z}, 615.0971$ $[\mathrm{M}-\mathrm{H}]^{-}$corresponding to the molecular formula of $\mathrm{C}_{28} \mathrm{H}_{24} \mathrm{O}_{16}\left(\mathrm{C}_{28} \mathrm{H}_{24} \mathrm{O}_{16}-\mathrm{H}, 615.0986\right.$, error of
1.5 millimass). Compounds (4) and (3) had similar spectral data (Table 1), however, the former had seven carbon signals more than the latter, including a carbonyl carbon, three oxygenated aromatic carbons, two aromatic methines and one substituted aromatic carbons. Those differences demonstrated that (4) was similar to (3) but further containing a galloyl moiety. In the HMBC spectrum of (4), the anomeric $\mathrm{H}-1$ " signal at $\delta_{H} 5.50(1 \mathrm{H}, d, 1.5 \mathrm{~Hz})$ correlated with the myricetin C-3 resonance at $\delta_{C}$ 133.5 , and the rhamnose $\mathrm{H}-2^{\prime \prime}$ signal at $\delta_{H} 5.47$ correlated with the galloyl ester carbon resonance at $\delta_{C}$ 165.0. Accordingly, the galloylrhamnosyl was determined to be attached to the myricetin $\mathrm{C}$ 3 position, and the galloyl moiety was attached to the rhamnose $\mathrm{C}-2$ position (Fig. 1). Thus, (4) was determined as myricetin 3-O-(2" $O$-galloyl)- $\alpha$-Lrhamnopyranoside.

The spectral data of (5) were closely related to those of (4) with signals of a rhamnose unit, a myricetin skeleton and a galloyl group. The comparison of the ${ }^{1} \mathrm{H}$ NMR spectrum of (5) with that of (4) (Table 1) showed that the H-3" was downfield shifted suggesting the galloyl group was located at the rhamnose $\mathrm{C}-3$ " position, which was further confirmed by the HMBC cross-peak of the rhamnose proton signal H-3" at $\delta_{\mathrm{H}} 5.04$ 
with the carbon signal at $\delta_{C} 165.7(\mathrm{C}=\mathrm{O}$ of galloyl). Based on these findings, the structure of (5) was concluded to be myricetin 3-O-(3"-Ogalloyl)- $\alpha$-L-rhamnopyranoside (or myricitrin 3 "$O$-gallate).

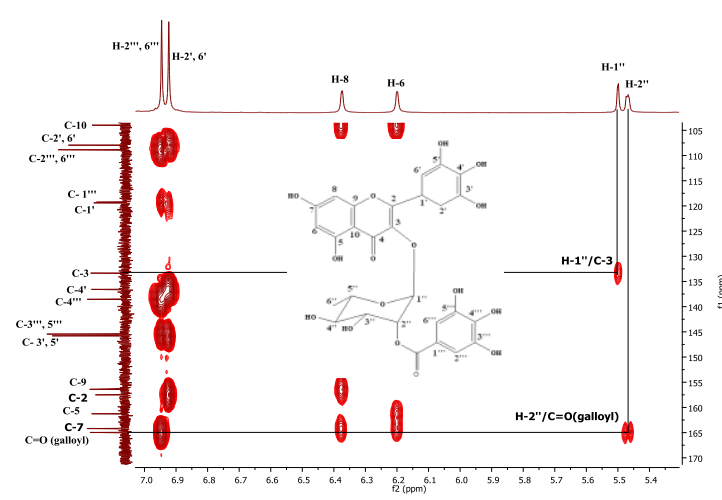

Fig. 2. The expanded HMBC spectrum of (4)

The HR-ESI-MS spectrum of (6) demonstrated a quasimolecular ion peak at $\mathrm{m} / \mathrm{z}$ $315.0120 \quad[\mathrm{M}-\mathrm{H}]^{-} \quad$ corresponding to the molecular formula of $\mathrm{C}_{15} \mathrm{H}_{8} \mathrm{O}_{8} \quad\left(\mathrm{C}_{15} \mathrm{H}_{8} \mathrm{O}_{8}-\mathrm{H}\right.$, 315.0141, error of 2.1 millimass). The ${ }^{1} \mathrm{H}$ NMR spectrum of (6) showed three proton signals at $\delta_{H}$ $7.51(1 \mathrm{H}, s), 7.42(1 \mathrm{H}, s)$ and $4.03(3 \mathrm{H}, s)$. The ${ }^{13} \mathrm{C}$ NMR spectrum of (6) showed 15 carbon signals including a methoxy carbon at $\delta_{C} 60.9,12$ signals in the zone from $\delta_{C}$ 109-152, two carboxyl carbon signals at $\delta_{C} 158.9$ and 159.1. Therefore, compound (6) had two gallic acid units. The comparison of spectral data of (6) with 3-O-methylellagic acid [7] showed good compatibility. Therefore, (6) was identified as 3 $O$-methylellagic acid.

The combination of ${ }^{1} \mathrm{H}$ NMR, DEPT and HSQC spectra of (7) showed the presence of four methyl singlets at $\delta_{H} 0.87,1.11,1.13$ and 2.25, two non-equivalent methylenes at $\delta_{H} 1.25(1 \mathrm{H}-$ 2a, $d d, 13.0,10.5 \mathrm{~Hz}), 1.62(1 \mathrm{H}-2 \mathrm{~b}, d d d, 13.0$, $3.5,1.0 \mathrm{~Hz})$ and $1.73(1 \mathrm{H}-4 \mathrm{a}, d d, 14.5,9.0 \mathrm{~Hz})$, $2.36(1 \mathrm{H}-4 \mathrm{~b}, \quad d d d, 14.5,5.0,1.0 \mathrm{~Hz})$, an oxygenated methine at $\delta_{H} 4.17(1 \mathrm{H}, m)$ and two olefinic protons at $\delta_{H} 6.03(1 \mathrm{H}, d, 16.0 \mathrm{~Hz})$ and $7.07(1 \mathrm{H}, d, 16.0 \mathrm{~Hz})$. The combination of ${ }^{13} \mathrm{C}$ NMR and DEPT spectra showed 13 carbon signals including four methyls $\left(\delta_{C}\right.$ 19.7, 25.0, 27.4 and 28.7), two methylenes $\left(\delta_{C} 37.7\right.$ and 43.2), one oxymethine $\left(\delta_{C} 68.3\right)$, two olefinic carbons $\left(\delta_{C} 132.4\right.$ and 143.0), three quaternary carbons $\left(\delta_{C} 34.5,68.7\right.$ and 68.9), and one carbonyl carbon ( $\delta_{C}$ 197.4). The HMBC experiment showed cross-peaks of $\mathrm{H}-4 \mathrm{~b}, \mathrm{H}-13$ with the oxygenated carbon $\mathrm{C}-5\left(\delta_{C} 68.7\right)$, and $\mathrm{H}-$ 2a, H-2b, H-4a and H-4b with C-3 $\left(\delta_{C} 68.3\right)$. Meanwhile, the tertiary oxygenated carbon was attributed at C-6 ( $\left.\delta_{C} 68.9\right)$. Based on the HMBC cross-peaks of proton signals of H-2a, H-2b, H4a, H-4b, H-7, H-8, H-11, H-12, H-13 with C-6 demonstrating that the side chain was attached to the six-membered ring at C- 6 . In addition, the HMBC cross-peaks of the trans-olefinic protons at $\delta_{H} 6.03(\mathrm{H}-8, d, 16.0 \mathrm{~Hz})$ and $7.07(\mathrm{H}-7, d$, $16.0 \mathrm{~Hz}$ ) to $\mathrm{C}-6$, as well as the carbonyl carbon (C-9), indicating the two conjugated olefinic carbons connected to the six-membered-ring and the carbonyl carbon, respectively. Therefore, (7) was 3,5,6-trihydroxy-7-megastigmen-9-one. The $\mathrm{H}-4 \mathrm{a}$ appeared as a double of doublets with $J_{\mathrm{gem}}$ $14.5 \mathrm{~Hz}$ and $J_{a a} 9.0 \mathrm{~Hz}$ in the ${ }^{1} \mathrm{H}$ NMR spectrum indicating its axial position. In the NOESY spectrum (Fig. 2), correlations of $\mathrm{H}-2 \mathrm{a}$ and $\mathrm{H} 4 \mathrm{a}$ with $\mathrm{H}-13$ devulged that the hydroxyl group at C5 was in axial position, whereas correlations of $\mathrm{H}-3$ with $\mathrm{H}-11$, of $\mathrm{H}-2 \mathrm{~b}$ as well as $\mathrm{H}-4 \mathrm{~b}$ with $\mathrm{H}-3$ indicated the equatorial position of the hydroxyl group at C-3. The NOESY correlations of H-7 with $\mathrm{CH}_{3}-12$ and $\mathrm{CH}_{3}-13$ as well as of $\mathrm{H}-8$ with $\mathrm{C}-13$ indicated the equatorial position for $6-\mathrm{OH}$ that was mentioned in a publication of stereostructure of (7) [8]. Therefore, the structure of (7) would be $(3 S, 5 R, 6 S, 7 E)$ - or $(3 R, 5 S, 6 R, 7 E)$ 3,5,6-trihydroxy-7-megastigmen-9-one.

Compound (7) was levorotatory $\left([\propto]_{D}^{25}\right.$ -199.9 ( c $0.08, \mathrm{CHCl}_{3}$ ) corresponding with that

\section{Trang 24}


of $\quad(3 S, 5 R, 6 S, 7 E)-3,5,6$-trihydroxy-7-

megastigmen-9-one in the literature [1]. Therefore, compound was identified as (3S,5R,6S,7E)-3,5,6-trihydroxy-7-megastigmen9-one.

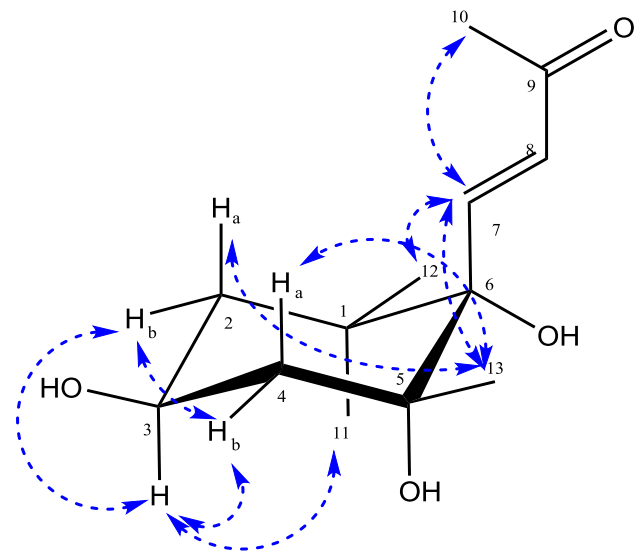

Fig. 3. Key NOESY correlations of (7)
The ${ }^{13} \mathrm{C}$ NMR spectrum of (8) disclosed a carboxyl carbon at $\delta_{C} 167.5$, four carbon signals of one symmetrical aromatic ring including three oxygenated carbon signals at $\delta_{C} 145.4$ (C-3, C5), $138.0(\mathrm{C}-4)$, two aromatic methine signals at $\delta_{\mathrm{C}} 108.7(\mathrm{C}-2, \mathrm{C}-6)$, and a quaternary carbon signal at $\delta_{C} 120.5(\mathrm{C}-1)$. It corresponded to an aromatic proton signal at $\delta_{H} 6.91(2 \mathrm{H}, s)$ in the ${ }^{1} \mathrm{H}$ NMR spectrum. Therefore, compound (8) was identified as gallic acid through the comparison of its NMR data with the published ones in the literature [4].

The glucosidase inhibition assay was applied on extracts and pure isolated compounds, and the result showed hat compounds (1), (4), (5), (6) and (8) exhibited good activities with the $\mathrm{IC}_{50}$ values in the range of $1.3-19.3 \mu \mathrm{M}$ whereas extracts displayed strong activities.

Table 2. The result of $\alpha$-glucosidase inhibition activity

\begin{tabular}{l|cccccccccccccccc}
\hline & \multicolumn{1}{|c}{$\mathrm{IC}_{50}(\mu \mathrm{g} / \mathrm{mL})$} & \multicolumn{1}{c}{$\mathrm{IC}_{50}(\mu \mathrm{M})$} \\
\hline $\begin{array}{l}\text { Extract/ } \\
\text { compound }\end{array}$ & $\begin{array}{l}\text { Methanol } \\
\text { residue }\end{array}$ & $\mathbf{A}$ & $\mathbf{B}$ & $\mathbf{C}$ & $\mathbf{D}$ & Acar $^{\mathrm{b}}$ & $\mathbf{1}$ & $\mathbf{2}$ & $\mathbf{3}$ & $\mathbf{4}$ & $\mathbf{5}$ & $\mathbf{6}$ & $\mathbf{8}$ & Acarbose \\
\hline & $<0.1$ & 11 & $<0.1$ & 0.3 & 2.2 & 138.2 & 1.3 & 179.5 & $>250$ & 3.6 & 7.0 & 4.7 & 19.3 & 214.5 \\
\hline
\end{tabular}

\section{CONLUSION}

From leaves of Lumnitzera racemosa Willd. eight compounds were isolated: myricetin (1), quercetin (2), myricetin 3-O- $\alpha-\mathrm{L}-$ rhamnopyranoside (3), myricetin 3-O- $\left(2^{\prime \prime}\right.$ galloyl)- $\alpha$-L-rhamnopyranoside (4), myricetin 3$O$-(3"-galloyl)- $\alpha$ - L-rhamnopyranoside (5), 3-Omethylellagic $\quad(6), \quad(3 S, 5 R, 6 S, 7 E)-3,5,6-$ trihydroxy-7-megastigmen-9-one (7) and gallic acid (8). Among them, (3), (4), (5), (7) were found for the first time in the Lumnitzera species.
The $\alpha$-glucosidase inhibition was evaluated on isolated compounds. The result of $\alpha$-glucosidase inhibitory activity showed that all extracts and most of isolated compounds exhibited good activities than the positive control acarbose. Among isolated compounds, (1), (4), (5) (6) and (8) displayed strong $\alpha$-glucosidase inhibitory activities with the $\mathrm{IC}_{50}$ values in the range of $1.3-19.3 \mu \mathrm{M}$.

Acknowledgment: This research is funded by Vietnam National University Ho Chi Minh City (VNU-HCM) under grant number A2015-18.02. 


\section{Một số hợp chất cô lập từ lá cây Cóc trắng (Lumnitzera racemosa Willd.) mọc ở Việt Nam}

- Nguyễn Hoài Phương

- Nguyễn Thị Lệ Thủy

- Nguyễn Trung Đức

- Nguyễn Thị Thanh Mai

- Nguyễn Kim Phi Phụng

Trường Đại học Khoa học Tự nhiên, ĐHQG-HCM

\section{TÓM TẮT}

Từ lá cây L. racemosa, tám hợp chất đã đuợc cô lạp: myricetin (1), quercetin (2), myricetin 3$O-\alpha$-L-rhamnopyranoside (3), myricetin 3-O-(2"$O$-galloyl- $\alpha$-L-rhamnopyranoside) (4), myricetin 3-O-(3"-O-galloyl- $\alpha$-rhamnopyranoside) (5), 3O-methylellagic acid (6), (3S,5R,6S,7E)-3,5,6trihydroxy-7-megastigmene-9-one (7) và gallic acid (8). Cấu trúc hoá học của các hơp chất cô lập được xác định bằng phổ cộng huơong tù̀ hạt nhân và khối phổ phân giải cao cũng nhu so sánh số liệu của chúng với tài liệu tham khảo. Ngoài ra các cao chiết và hợp chất cô lập được thử hoạt tính ức chế enzyme $\alpha$-glucosidase. Kết quả cho thấy các hợp chất 1, 4, 5, 6 và 8 có hoạt tính manh với giá trị IC $C_{50}$ trong khoảng 1.3-19.3 $\mu M$.

Tù khóa: Lumnitzera racemosa Willd., Chi lumnitzera, Flavonoid, Sesquiterpene khung megastigmane

\section{REFERENCES}

[1]. J.H. Park, D.G. Lee, S.W. Yeon, H.S. Kwon, J.H. Ko, D.J. Shin, H. S. Park,Y.S Kim, M.H. Bang, N.I. Baek, Isolation of megastigmane sesquiterpenes from the Silkworm (Bombyx mori L.) droppings and their promotion activity on $\mathrm{HO}-1$ and SIRT1, Arch Pharm. Res., 34, 4, 533-542 (2011).

[2]. K.Y. Kim, K.A. Nam, H. Kurihara, S.M Kim, Potenta-glucosidase inhibitors purified from the red alga Grateloupia elliptica, Phytochemistry, 69, 2820-2825 (2008).

[3]. N.P. Thao, B.T.T. Luyen, C.N. Diep, B.H. Tai, E.J. Kim, H.K. Kang, S.H. Lee, H.D. Jang , N.T. Cuong, N.V. Thanh, N.X. Cuong, N.H. Nam, C.V. Minh, Y.H. Kim, In vitro evaluation of the antioxidant and cytotoxic activities of constituents of the mangrove Lumnitzera racemosa Willd., Arch. Pharm. Res., 38, 4, 446-455 (2015).
[4]. O.A. Eldahshan, Isolation and structure elucidation of phenolic compounds of Carob leaves grown in Egypt, Curr. Res. J. Biol. Sci., 3, 1, 52-55 (2011).

[5]. S. Yaya, K.A.B. Benjamin, B. Fanté, S. Sorho, T.S. Amadou, C.J. Marie, Flavonoids and gallic acid from leaves of Santaloides afzelii (Connaraceae), Rasāyan J. Chem., 5, 3, 332-337 (2012).

[6]. T.J. Mabry, K.R. Markham and M.B. Thomas, The Systematic Identification of Flavonoids, Springer Verlag, New YorkHeidelberg-Berlin (1970).

[7]. T. Tanaka, Z. Jiang, I. Kouno., Distribution of ellagic acid derivatives and a diarylheptanoid in wood of Platycarya strobilacea, Phytochemistry, 47, 5, 851-854 (1998).

[8]. Y. Sun, Y.C. Zhan, Y. Sha, Y.H.. Pei, Norisoprenoids from Ulva lactuca, J. Asian Nat. Prod. Res., 9, 4, 321-325 (2007).

Trang 26 